\title{
An evaluation to assess the knowledge regarding prevention and management of chickenpox in children among mothers having children below 10 years of age residing at selected community area of Allahabad (India)
}

\author{
Jemy Elizabeth Joseph* and Shiju Mathew \\ * Dept. of Emergency Pediatrics, Ministry of Health, King Saud Medical City \\ P.O. Box No. 7855, Riyadh 111117, Kingdom of Saudi Arabia \\ Dept. of Biotechnology, Marthoma College of Science and Technology \\ Chadayamangalam P.O., Ayur- 691534 India \\ *Corresponding author E-mail: jemyshiju@gmail.com
}

\begin{abstract}
Chickenpox is a worldwide disease and is no respecter race or class. The incidence increases in spring \& winter months in the temperate zones. In the tropics, the peak incidence is during winter and early spring. The disease in fact started spreading from February itself. Lack of knowledge among common people on preventing water contamination is helping the virus to spread rapidly. The descriptive study attempts to assess the knowledge regarding prevention and management of chickenpox among mothers of below 10 years of age children who are residing at Naini, Allahabad with a view to develop an information booklet. Method: The study involved single group test without a control, using nonexperimental descriptive design, with non-probability convenient sampling. 60 women were involved in data collection by using structured questionnaire. The study came to an end by implementation of information booklet on chickenpox and its prevention and management, and the results were described using descriptive and inferential statistics. Results: The overall mean knowledge score was found to be $48.86 \%$ and S.D 5.87. The highest mean knowledge score was found on general health $(46.5 \%)$. The mean knowledge score varied from $46.5 \%$ to $55.6 \%$ on different aspects of chickenpox. Chi-square test implies that there was a statistically significant association between selected demographic variables with knowledge of prevention and home care management of chickenpox at 5 percent level. Conclusion: The overall findings of the study clearly showed that there is lack of knowledge of prevention and home care management of chickenpox among mothers and the results revealed that distribution of information booklet on chickenpox and its prevention and management will be helpful for the women to gain knowledge.
\end{abstract}

Keywords: Chicken pox, Infants, Knowledge, Management, Mother and Prevention

\section{Introduction}

A variety of skin infection may occur in children in the school age group. As children are inquisitive and mobile, they come into contact with a variety of people and animals. The close proximity in the school setting provides opportunity to be exposed to infectious agents (viruses, bacteria, fungus, insects and animals) in addition; children tend to share personal items. Chickenpox occurs worldwide and is endemic in large cities. Outbreaks occur sporadically, usually in areas with large groups of susceptible children. It affects all races and both sexes equally. It can occur at any age, but it is most common among children between age group 2 to 8 . [1]

Chickenpox is highly infectious disease caused by one Varicella Zooster Virus belongs to the group of herpes viruses. There are many different types of herpes virus, but one feature which they all have is that they lie dormant in the body after the initial infection, and can reactivate much later. The disease caused by the reactivation of the chickenpox virus is known as shingles and it may occur when the immune system is run down. Chickenpox is highly contagious. Like most viral infections, the chickenpox virus is transmitted from person to person by droplet spread, e.g. Sneezing, and by close contact with an infected person such as touching the fluid oozing from the blisters or using the infected persons clothes or towels.[2] 
Most children will contact chickenpox when they are young and it is usually a mild illness in children; though can be more serious in teenagers and adults. The incubation period is from 14 to 21 days. The child is infectious from about two days before the rash appears until all the spots have dried up which can take up to ten days. Most people get chickenpox at least once in their lifetime. If you have had chickenpox before it is very unlikely that you would get it again. The infection produces antibodies that help in fight with virus, if it attacks again. The infection is mild in children but the severity increases in adults and pregnant women. [3,4]. The best way to prevent varicella is through vaccination. Most health experts recommend that all children of 12 months age and older who have not had chicken pox get one dose at 12 to 15 months and a second, booster dose at 4 to 6 years old. Adolescents and adults who are not already immune to the chickenpox virus need two doses at least 4 weeks apart. The varicella vaccine has been shown to be $95 \%$ effective in preventing moderate to severe infection, and 70 to $90 \%$ against mild infection. Varicella isn't necessarily a mild illness, and it's important for parents to know that choosing not to vaccinate their children not only places their child at risk for infection requiring medical care, but also places members of the community at risk [5-10].

\section{Materials and Methods}

\section{Conceptual framework}

A conceptual framework is an analogous to the frame of a house, just as the foundation supports a house. A theoretical framework provides a rationale for predictions about the relationships among variables of a research study. Conceptualization refers to the process of refining general or abstract ideas, which are formulated by generalizing from particular manifestations of certain behavior or characteristics ${ }^{17,18}$. The conceptual framework for the present study is based on Health promotion Model. Persons have to initiate and do active roles and this behavior is goal directed for raising this health and good living. The Pender's health Promotion Model first appears in nursing literature in the early 1980s and later the revised health promotion model appears in 1996. In revised health promotion model, Pender represents that raising health status and avoiding illness are the major motivational significance in health promotional behavioral practice. This model is explained about the variables and this interrelationships that affect health promoting behavior. This model focuses on the following 3 areas: Client cognitive - perceptual factors, Modifying factors and Participating in health promoting behaviors [11-16].

\subsection{Nola Pender's health promotion model}

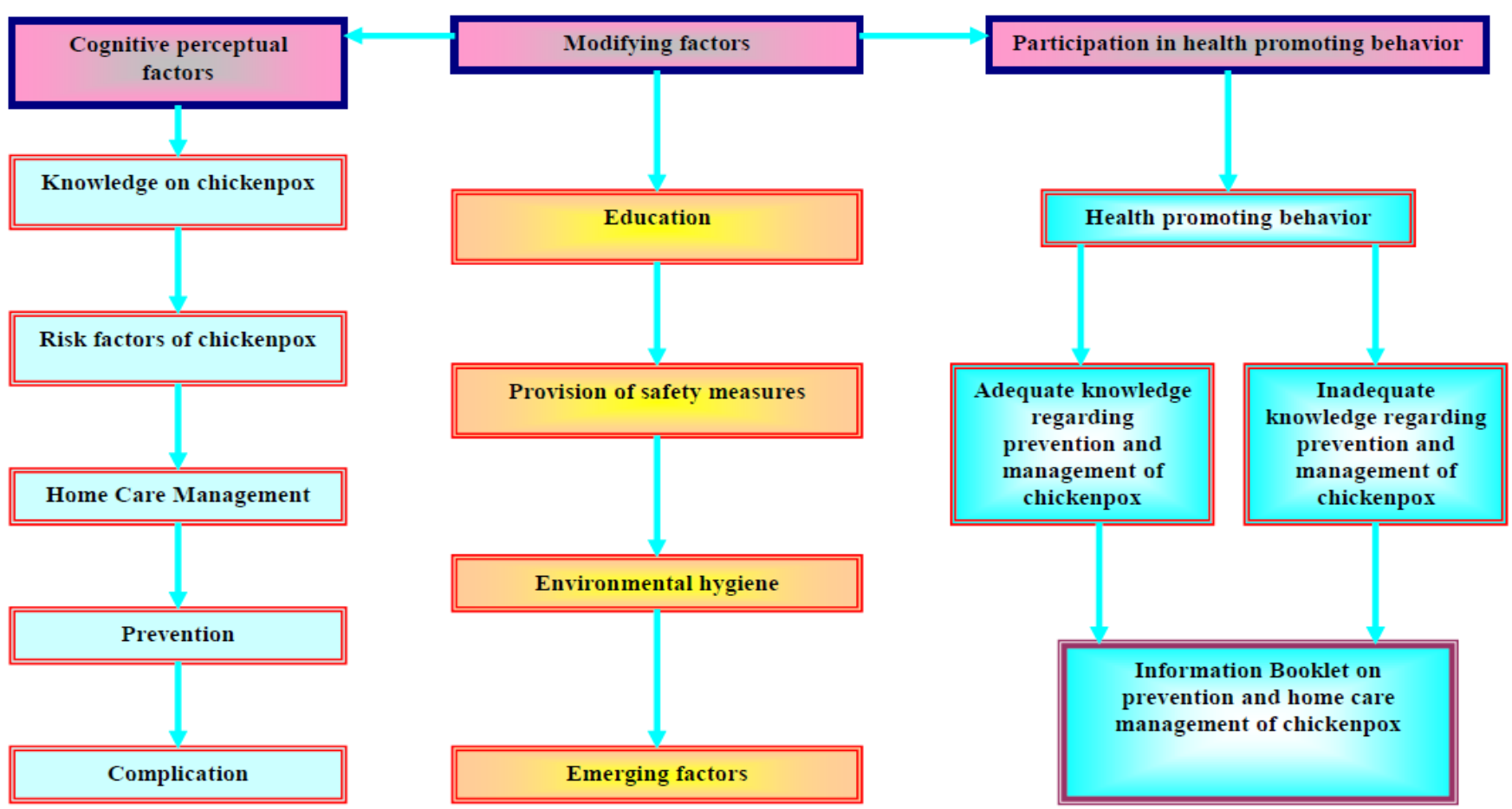

Figure 1: Schematic representation of theoretical frame work on a study to assess the Knowledge regarding Prevention and Home care management of chickenpox among mothers based on Pender's health promotion model. 


\subsection{Research design}

The research design provides an overall or blue print to carry out the study. The research design used in this study is Descriptive design. The non probability convenience sampling was adopted to collect the data. The level of Knowledge regarding Prevention and management of chickenpox among Mothers residing at Naini, Allahabad.

\subsection{Sampling}

Sample : Sample refers to the sub set of population. Sampling refers to the process of selecting a portion of population to represent the entire population ${ }^{17}$. Mothers, who have below 10 years of age and within the age group 25-45 years of age at Naini, Allahabad. The sample consists of 60 mothers residing at Naini, Allahabad.

\subsection{Sampling Technique}

Sampling technique is a process of selecting representative units of population for study in a research[17-25]. In this study, subjects were selected by non probability convenience sampling technique. After selection of setting by convenient sampling method, selection was based on inclusion and exclusion criteria.

\subsection{Data collection}

The investigator personally visited each respondent and introduced him. The nature of the study was briefly explained to the staff nurses and it was ensured by the investigator that the routines of the hospital would not be disrupted. 60 mothers were selected by non-probability convenience sampling technique [26-31]. The questionnaire was administered to the mothers and each sample took 40 minutes for the completion of questionnaire schedule.

\subsection{Plan for Data Analysis}

The data were analyzed in terms of the objectives of the study using descriptive and inferential statistics.

The plan for data analysis was as follows:

1. The frequencies and percentage for analyzing demographic variables.

2. Mean, Mean percentage and Standard deviation to assess the Knowledge of Mothers regarding Prevention and home care management of chickenpox.

3. Chi-square test, to find out the relationship between Knowledge score and demographic variables.

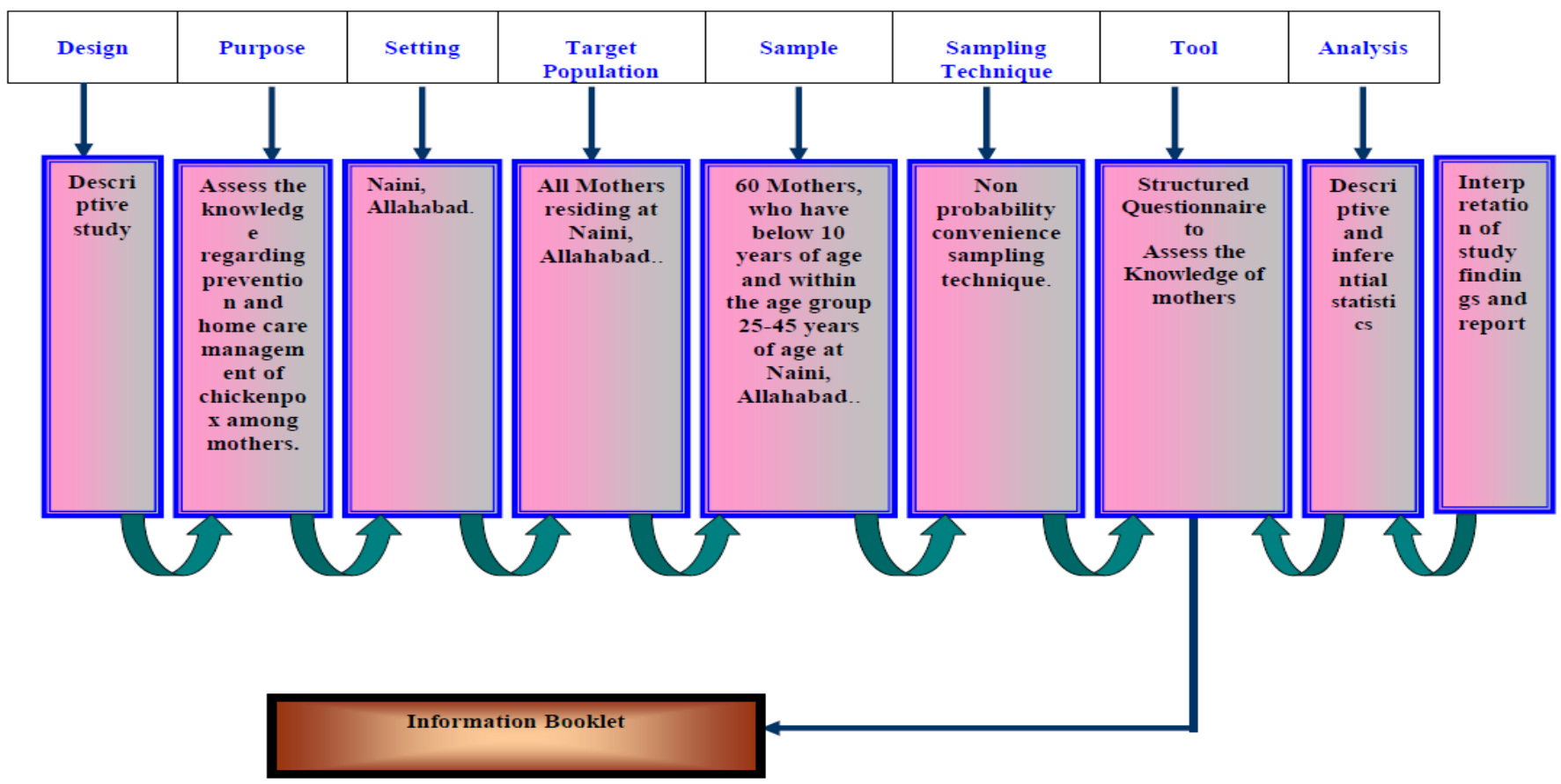

Figure 2: Schematic Representation of the Study 


\section{Main results}

\subsection{Data on demographic variables of the mothers}

Table 1: The frequency and percentage distribution of the mothers according to the age group $n=60$

\begin{tabular}{clll}
\hline S. No. & Demographic Variable & Frequency & Percentage \\
\hline 1 & Age in years & & \\
& $25-30$ years & 15 & $25 \%$ \\
& $31-35$ years & 26 & $43 \%$ \\
& $36-40$ years & 10 & $17 \%$ \\
& $41-45$ & 9 & $15 \%$ \\
& TOTAL & 60 & $100 \%$ \\
\hline
\end{tabular}

Table 2: The frequency and percentage distribution of the mothers according to the educational status $n=60$

\begin{tabular}{cccc}
\hline S. No. & Demographic variable & Frequency & Percentage \\
\hline 2. & Educational Status & 21 & $35 \%$ \\
Primary & 17 & $28.33 \%$ \\
High school & 16 & $26.67 \%$ \\
Graduate & 6 & $10 \%$ \\
Others -specify & 60 & $100 \%$ \\
TOTAL & &
\end{tabular}

Table 3: The frequency and percentage distribution of the mothers according to occupation $n=60$

\begin{tabular}{clll}
\hline S. No. & Demographic variable & Frequency & Percentage \\
\hline 3. & Occupation & 31 & $51.67 \%$ \\
& House wife & 17 & $28.33 \%$ \\
& Health Professional & 12 & $20 \%$ \\
& Other Professionals & 60 & $100 \%$ \\
\hline
\end{tabular}

Table 4:The frequency and percentage distribution of mothers according to family monthly income $n=60$

\begin{tabular}{clcc}
\hline S. No. & Demographic variable & Frequency & Percentage \\
\hline 4. & Family monthly income (Rs.) & & $43.34 \%$ \\
& $<3000$ & 26 & $38.33 \%$ \\
$3001-6000$ & 23 & $18.33 \%$ \\
$6001-9000$ & 11 & $100 \%$ \\
TOTAL & 60 & \\
\hline
\end{tabular}


Table5: The frequency and percentage distribution of the mothers according to the No of children $n=60$

\begin{tabular}{|c|c|c|c|}
\hline S. No. & Demographic variables & Frequency & Percentage \\
\hline \multirow[t]{6}{*}{5} & No of children & & \\
\hline & One & 6 & $10 \%$ \\
\hline & Two & 25 & $41.67 \%$ \\
\hline & Three & 23 & $38.33 \%$ \\
\hline & Above three & 6 & $10 \%$ \\
\hline & Total & 60 & $100 \%$ \\
\hline
\end{tabular}

Table 6: The frequency and percentage distribution of the mothers according to the type of family $n=60$

\begin{tabular}{|c|c|c|c|}
\hline S. No. & Demographic variables & Frequency & Percentage \\
\hline \multirow[t]{4}{*}{2} & Type of family & & \\
\hline & Joint & 5 & $8.33 \%$ \\
\hline & Nuclear & 55 & $91.67 \%$ \\
\hline & TOTAL & 60 & $100 \%$ \\
\hline
\end{tabular}

Table 7: The frequency and percentage distribution of the mothers according to Area of residence $n=60$

\begin{tabular}{cllc}
\hline S. No. & Demographic variable & Frequency & Percentage \\
\hline 7. & Area of residence & & $16.67 \%$ \\
& Urban & 10 & $28.33 \%$ \\
& Semi urban & 17 & $55 \%$ \\
& Rural & 33 & $100 \%$ \\
\hline
\end{tabular}

Table- 8: The frequency and percentage distribution of the mothers according to Source of information $n=60$

\begin{tabular}{|c|c|c|c|}
\hline S. No. & Demographic variables & Frequency & Percentage \\
\hline \multirow[t]{7}{*}{8} & Source of information & & \\
\hline & In-service education & 20 & $33.33 \%$ \\
\hline & Journals/Books & 5 & $8.33 \%$ \\
\hline & TV/Radio & 2 & $3.34 \%$ \\
\hline & Special training & 6 & $10 \%$ \\
\hline & Others & 27 & $45 \%$ \\
\hline & TOTAL & 60 & $100 \%$ \\
\hline
\end{tabular}




\subsection{Area-wise distribution of knowledge scores.}

Table 9: Aspect wise knowledge of respondents on impact of prevention and management of chickenpox.

\begin{tabular}{|c|c|c|c|c|c|c|}
\hline \multirow[b]{2}{*}{ S. NO. } & \multirow[t]{2}{*}{ ASPECTS } & \multirow[t]{2}{*}{ STATEMENT } & \multirow[t]{2}{*}{ SCORE RANGE } & \multicolumn{3}{|c|}{ KNOWLEDGE SCORE } \\
\hline & & & & MEAN & MEAN \% & SD \\
\hline 1 & General Awareness & 6 & $1-5$ & 2.9 & 48.3 & 1.2 \\
\hline 2 & Causes & 4 & $0-4$ & 1.98 & 49.5 & 1.04 \\
\hline 3 & Clinical manifestations & 4 & $0-4$ & 1.98 & 49.5 & 1.04 \\
\hline 4 & Prevention & 5 & $1-5$ & 2.2 & 45.3 & 7.2 \\
\hline 5 & $\begin{array}{l}\text { Home care } \\
\text { management }\end{array}$ & 9 & $1-9$ & 4.48 & 49.8 & 2.17 \\
\hline \multirow[t]{2}{*}{6} & $\begin{array}{l}\text { Complications of } \\
\text { chickenpox }\end{array}$ & 2 & $0-2$ & 0.99 & 49.8 & 0.035 \\
\hline & Combined & 30 & $20-43$ & 14.53 & 48.43 & 7.97 \\
\hline
\end{tabular}

Table 10: Overall Knowledge of mothers regarding prevention and home care management of chickenpox

\begin{tabular}{|c|c|c|c|}
\hline S. No. & Overall knowledge & Number & Percentage \\
\hline 1 & Inadequate $(<50 \%)$ & 44 & $73.33 \%$ \\
\hline 2 & Moderately adequate (50-75\%) & 10 & $16.67 \%$ \\
\hline \multirow[t]{2}{*}{3} & Adequate $(>75 \%)$ & 6 & $10 \%$ \\
\hline & Combined & 60 & $100 \%$ \\
\hline
\end{tabular}

\subsection{Findings related to association between demographic variables and knowledge levels of mothers regarding prevention and home care management of chickenpox.}

Table 11: Association between age and knowledge of respondents on prevention and home care management of chickenpox

\begin{tabular}{|c|c|c|c|c|c|c|c|c|c|}
\hline \multirow[t]{3}{*}{ Age group } & \multicolumn{8}{|c|}{ Level of knowledge score } & \multirow{3}{*}{$\begin{array}{c}\chi^{2} \\
\text { Value }\end{array}$} \\
\hline & \multicolumn{2}{|c|}{ Inadequate } & \multicolumn{2}{|c|}{ Moderately adequate } & \multicolumn{2}{|c|}{ Adequate } & \multicolumn{2}{|c|}{ Total } & \\
\hline & $\mathrm{N}$ & $\%$ & $\mathrm{~N}$ & $\%$ & $\mathrm{~N}$ & $\%$ & $\mathrm{~N}$ & $\%$ & \\
\hline 26-30years & 10 & 67 & 1 & 7 & 4 & 26 & 15 & 100 & \\
\hline 31-35years & 16 & 62 & 9 & 34 & 1 & 4 & 26 & 100 & $14.5^{\mathrm{S}}$ \\
\hline $36-40$ years & 2 & 20 & 7 & 70 & 1 & 10 & 10 & 100 & \\
\hline $41-45$ & 4 & 44 & 4 & 44 & 1 & 10 & 9 & 100 & \\
\hline Combined & 32 & 48 & 21 & 39 & 7 & 13 & 60 & 100 & \\
\hline
\end{tabular}

Table 12: Association between educational status and knowledge level of respondents

\begin{tabular}{|c|c|c|c|c|c|c|c|c|c|}
\hline \multirow[t]{3}{*}{ Educational Status } & \multicolumn{8}{|c|}{ Level of knowledge score } & \multirow{3}{*}{$\begin{array}{c}\chi^{2} \\
\text { Value }\end{array}$} \\
\hline & \multicolumn{2}{|c|}{ Inadequate } & \multicolumn{2}{|c|}{$\begin{array}{l}\text { Moderately } \\
\text { adequate }\end{array}$} & \multicolumn{2}{|c|}{ Adequate } & \multicolumn{2}{|c|}{ Total } & \\
\hline & $\mathrm{N}$ & $\%$ & $\mathrm{~N}$ & $\%$ & $\mathrm{~N}$ & $\%$ & $\mathrm{~N}$ & $\%$ & \\
\hline Primary & 21 & 100 & 0 & 0 & 0 & 0 & 21 & 100 & \\
\hline High school & 15 & 88.24 & 2 & 11.76 & 0 & 0 & 17 & 100 & \\
\hline Graduate & 5 & 31.25 & 6 & 37.5 & 5 & 31.25 & 16 & 100 & $49.79^{\mathrm{S}}$ \\
\hline Others & 3 & 50 & 2 & 33.33 & 1 & 16.67 & 6 & 100 & \\
\hline Combined & 44 & 73.33 & 10 & 16.67 & 6 & 10 & 60 & 100 & \\
\hline
\end{tabular}


S: Significant at $5 \%$ level, $\quad \chi^{2}(0.05,6 \mathrm{df})=12.59$

The association between educational status of the respondents and knowledge level was found to be statistically significant $\left(\chi^{2}=49.79^{\mathrm{S}}\right.$ at $\mathrm{P}<0.05$ level). It is clearly indicated that there is significant association between knowledge level and educational status on prevention and management of chickenpox.

Table 13: Association between occupation and knowledge level of respondents

\begin{tabular}{|c|c|c|c|c|c|c|c|c|c|}
\hline \multirow[t]{3}{*}{ Occupation } & \multicolumn{8}{|c|}{ Level of knowledge score } & \multirow{3}{*}{$\begin{array}{c}\chi^{2} \\
\text { Value }\end{array}$} \\
\hline & \multicolumn{2}{|c|}{ Inadequate } & \multicolumn{2}{|c|}{$\begin{array}{l}\text { Moderately } \\
\text { adequate }\end{array}$} & \multicolumn{2}{|c|}{ Adequate } & \multicolumn{2}{|c|}{ Total } & \\
\hline & $\mathrm{N}$ & $\%$ & $\mathrm{~N}$ & $\%$ & $\mathrm{~N}$ & $\%$ & $\mathrm{~N}$ & $\%$ & \\
\hline House wife & 28 & 90.32 & 2 & 6.45 & 1 & 3.23 & 31 & 100 & \\
\hline Health Professional & 8 & 47.06 & 5 & 29.41 & 4 & 23.53 & 17 & 100 & $1160^{\mathrm{S}}$ \\
\hline Other professional & 8 & 66.67 & 3 & 25 & 1 & 8.33 & 12 & 100 & \\
\hline Combined & 44 & 73.33 & 10 & 16.67 & 6 & 10 & 60 & 100 & \\
\hline
\end{tabular}

The association between occupation of the respondents and knowledge level was found to be statistically significant $\left(\chi^{2}=11.69^{\mathrm{S}}\right.$ at $\mathrm{P}<0.05$ level). It is clearly indicated that there is significant association between knowledge level and occupation of respondents on prevention and management of chickenpox.

Table 14: Association between family monthly income and knowledge level of respondents

\begin{tabular}{|c|c|c|c|c|c|c|c|c|c|}
\hline \multirow{3}{*}{$\begin{array}{l}\text { Family monthly } \\
\text { income }\end{array}$} & \multicolumn{8}{|c|}{ Level of knowledge score } & \multirow{3}{*}{$\begin{array}{c}\chi^{2} \\
\text { Value }\end{array}$} \\
\hline & \multicolumn{2}{|c|}{ Inadequate } & \multicolumn{2}{|c|}{$\begin{array}{l}\text { Moderately } \\
\text { adequate }\end{array}$} & \multicolumn{2}{|c|}{ Adequate } & \multicolumn{2}{|c|}{ Total } & \\
\hline & $\mathrm{N}$ & $\%$ & $\mathrm{~N}$ & $\%$ & $\mathrm{~N}$ & $\%$ & $\mathrm{~N}$ & $\%$ & \\
\hline Rs. $<3000$ & 24 & 92.31 & 2 & 7.69 & 0 & 0 & 26 & 100 & \\
\hline Rs.3001-6000 & 14 & 60.87 & 5 & 21.74 & 4 & 17.39 & 23 & 100 & $9.3^{\mathrm{NS}}$ \\
\hline Rs.6001-9000 & 6 & 54.55 & 3 & 27.27 & 2 & 18.18 & 11 & 100 & \\
\hline Combined & 44 & 73.33 & 10 & 16.67 & 6 & 10 & 60 & 100 & \\
\hline
\end{tabular}

NS: Non Significant at $5 \%$ level,

$\chi^{2}(0.05,4 \mathrm{df})=9.49$

The data subjected for statistical test indicates that there is statistically non significant association $\left(\chi^{2}=9.3^{\mathrm{NS}}\right.$ at $\mathrm{P}<0.05$ level). It is clearly indicated that there is no significant association between family monthly income and knowledge level on prevention and management of chickenpox.

Table 15: Association between No of children and Knowledge level of respondents

\begin{tabular}{|c|c|c|c|c|c|c|c|c|c|}
\hline \multirow{3}{*}{$\begin{array}{l}\text { Years of } \\
\text { experience }\end{array}$} & \multicolumn{8}{|c|}{ Level of knowledge score } & \multirow{3}{*}{$\begin{array}{c}\mathrm{X}^{2} \\
\text { Value }\end{array}$} \\
\hline & \multicolumn{2}{|c|}{ Inadequate } & \multicolumn{2}{|c|}{ Moderately adequate } & \multicolumn{2}{|c|}{ Adequate } & \multicolumn{2}{|c|}{ Total } & \\
\hline & $\mathrm{N}$ & $\%$ & $\mathrm{~N}$ & $\%$ & $\mathrm{~N}$ & $\%$ & $\mathrm{~N}$ & $\%$ & \\
\hline One & 1 & 16.67 & 4 & 66.66 & 1 & 16.67 & 6 & 100 & $6.65^{\mathrm{NS}}$ \\
\hline Two & 1 & 4.34 & 19 & 82.62 & 3 & 13.04 & 23 & 100 & \\
\hline Three & 0 & 0 & 23 & 92.0 & 2 & 8.0 & 25 & 100 & \\
\hline Above three & 0 & 0 & 5 & 83.33 & 1 & 16.67 & 6 & 100 & \\
\hline Combined & 2 & 3.33 & 51 & 85.0 & 7 & 11.67 & 60 & 100 & \\
\hline
\end{tabular}

NS: Non-Significant,

$$
\mathrm{X}^{2}(0.05,6 \mathrm{df})=12.592
$$

The data shows that there is statistically no significant association $\left(\mathrm{X}^{2}=6.65\right.$ at $\mathrm{P}>0.05$ level $)$. 
Table 16: Association between Type of family and Knowledge level of respondents

\begin{tabular}{|c|c|c|c|c|c|c|c|c|c|}
\hline \multirow[t]{3}{*}{ Gender } & \multicolumn{8}{|c|}{ Level of knowledge score } & \multirow{3}{*}{$\begin{array}{c}\mathrm{X}^{2} \\
\text { Value }\end{array}$} \\
\hline & \multicolumn{2}{|c|}{ Inadequate } & \multicolumn{2}{|c|}{ Moderately adequate } & \multicolumn{2}{|c|}{ Adequate } & \multicolumn{2}{|c|}{ Total } & \\
\hline & $\mathrm{N}$ & $\%$ & $\mathrm{~N}$ & $\%$ & $\mathrm{~N}$ & $\%$ & $\mathrm{~N}$ & $\%$ & \\
\hline Nuclear & 1 & 20.0 & 3 & 60.0 & 1 & 20.0 & 5 & 100 & $5.14^{\mathrm{NS}}$ \\
\hline Joint & 1 & 1.81 & 48 & 87.28 & 6 & 10.91 & 55 & 100 & \\
\hline combined & 2 & 3.33 & 51 & 85.0 & 7 & 11.67 & 60 & 100 & \\
\hline
\end{tabular}

The data indicates that the association is statistically non significant $\left(\mathrm{X}^{2}=5.14\right.$ at $\mathrm{P}>0.05$ level $)$.

Table 17: Association between Area of residence and knowledge level of respondents

\begin{tabular}{|c|c|c|c|c|c|c|c|c|c|}
\hline \multirow{3}{*}{ Type of residence } & \multicolumn{8}{|c|}{ Level of knowledge score } & \multirow{3}{*}{$\begin{array}{c}\chi^{2} \\
\text { Value }\end{array}$} \\
\hline & \multicolumn{2}{|c|}{ Inadequate } & \multicolumn{2}{|c|}{$\begin{array}{l}\text { Moderately } \\
\text { adequate }\end{array}$} & \multicolumn{2}{|c|}{ Adequate } & \multicolumn{2}{|c|}{ Total } & \\
\hline & $\mathrm{N}$ & $\%$ & $\mathrm{~N}$ & $\%$ & $\mathrm{~N}$ & $\%$ & $\mathrm{~N}$ & $\%$ & \\
\hline Urban & 4 & 40 & 3 & 30 & 3 & 30 & 10 & 100 & \\
\hline Semi urban & 30 & 90.90 & 2 & 6.06 & 1 & 3.04 & 33 & 100 & $14.22^{\mathrm{S}}$ \\
\hline Rural & 10 & 58.83 & 5 & 29.41 & 2 & 11.76 & 17 & 100 & \\
\hline Combined & 44 & 73.33 & 10 & 16.67 & 6 & 10 & 60 & 100 & \\
\hline
\end{tabular}

The data subjected for statistical test indicates that there is statistically significant association $\left(\chi^{2}=14.22^{\mathrm{NS}}\right.$ at $\mathrm{P}<0.05$ level). It is clearly indicated that there is significant association between area of residence and knowledge level on prevention and management of chickenpox.

Table 18: Association between Source of information and Knowledge level of respondents

\begin{tabular}{|c|c|c|c|c|c|c|c|c|c|}
\hline \multirow{3}{*}{$\begin{array}{c}\text { Source of } \\
\text { information }\end{array}$} & \multicolumn{8}{|c|}{ Level of knowledge score } & \multirow{3}{*}{$\begin{array}{c}\mathrm{X}^{2} \\
\text { Value }\end{array}$} \\
\hline & \multicolumn{2}{|c|}{ Inadequate } & \multicolumn{2}{|c|}{$\begin{array}{l}\text { Moderately } \\
\text { adequate }\end{array}$} & \multicolumn{2}{|c|}{ Adequate } & \multicolumn{2}{|c|}{ Total } & \\
\hline & $\mathrm{N}$ & $\%$ & $\mathrm{~N}$ & $\%$ & $\mathrm{~N}$ & $\%$ & $\mathrm{~N}$ & $\%$ & \\
\hline $\begin{array}{l}\text { In-service } \\
\text { education }\end{array}$ & 0 & 0 & 18 & 90.0 & 2 & 10.0 & 20 & 100 & $27.72^{\mathrm{S}}$ \\
\hline Journals/Books & 1 & 20.0 & 2 & 40.0 & 2 & 40.0 & 5 & 100 & \\
\hline TV/Radio & 1 & 50.0 & 1 & 50.0 & 0 & 0 & 2 & 100 & \\
\hline Special training & 0 & 0 & 4 & 66.67 & 2 & 33.33 & 6 & 100 & \\
\hline Others & 0 & 0 & 26 & 96.3 & 1 & 3.7 & 27 & 100 & \\
\hline Combined & 2 & 3.33 & 51 & 85.0 & 7 & 11.67 & 60 & 100 & \\
\hline
\end{tabular}

S: Significant at $5 \%$ level,

$$
\mathrm{X}^{2}(0.05,8 \mathrm{df})=15.507
$$

The association between source of information of the respondents and knowledge level was found to be statistically significant $\left(\mathrm{X}^{2}=27.72\right.$ at $\mathrm{P}<0.05$ level). This table indicates that there is significant association between Knowledge level and source of information of the respondents on Prevention and home care management of chickenpox.

\subsection{Discussion}

The non- experimental, descriptive design was adopted for the present study. Convenient sampling technique was used to select the samples. The data was collected from 60 mothers from Naini, Allahabad using a structured questionnaire and observational checklist. 


\subsubsection{Description of demographic characteristics}

Table1 indicates that higher per cent (43\%) of the respondents were belonging to the age group of 31-35 years. About $25 \%$ were belonging to $36-40$ years of age group; $15 \%$ were belonging to age group of $41-45$ years.

Table -2 shows educational status $-26.67 \%$ were graduates; $28.33 \%$ had schooling till high school level. $35 \%$ and $10 \%$ had schooling till primary school and other education.

Table -3 shows depicts that $51.67 \%$ were house wives, $28.33 \%$ were health professionals and $20 \%$ were other professionals.

Table 4 shows that $43.34 \%$ have $<3000$ Rs. salary. $38.33 \%$ and 18.33\% had salary of Rs.3001-6000 and Rs.6001-9000 respectively.

Table-5 depicts the distribution of sample according to the No of children. The maximum of $25(41.67 \%)$ mothers have two children, followed by 23 (38.33\%) mothers have three children and the mothers have one and above three children with $6(10 \%)$.

Table 6 depicts in relation to type of family, majority (91.67\%) of respondents were found to be nuclear family as compared to joint family $(8.33 \%)$ in the study group.

Table 7 depicts in relation to type of family, majority (91.67\%) of respondents were found to be nuclear family as compared to joint family $(8.33 \%)$ in the study group.

Table 8 shows source of information $-45 \%$ of the respondents got information from others, $33 \%$ of the respondents got information from In-service education, $10 \%$ of the respondents got information from special training, $8.33 \%$ of the respondents were belonged to Journals/Books followed by $3.34 \%$ of the respondents were belonged to TV/Radio.

Table 15 reveals that the mean knowledge score is $48.43 \%$ and SD 7.97. The highest mean knowledge score is related to general health $(49.8 \%)$, whereas, the lowest mean knowledge score is related to prevention and home care management of chickenpox (45.3\%). The aspect wise mean knowledge score ranged between $49.8 \%$ to $45.3 \%$. The result shows $73.33 \%$ of the respondents possess inadequate knowledge as compared to $16.67 \%$ of respondent noticed with moderately adequate and $10 \%$ of respondents possess adequate knowledge on prevention and home care management of chickenpox. This shows that there is lack of knowledge among mothers in all aspects regarding prevention and home care management of chickenpox. Lack of knowledge among mothers regarding prevention and home care management of chickenpox was identified by researchers in the following studies which is similar to the present study.

\subsubsection{The association between knowledge level and selected demographic variables of mothers}

There was significant relationship found between the demographic variables such as age $(\chi 2=15.5)$, education $(\chi 2=12.59)$, Occupation $(\chi 2=11.69)$, Area of residence $\left(\chi^{2}=9.49\right)$, source of information $(\chi 2=15.50)$ and knowledge of mothers at $\mathrm{p}<0.05$ level. There was no significant relationship found between the demographic variable; income $(\chi 2=9.3)$, No of children $(\chi 2=12.59)$, Type of family $(\chi 2=5.59)$ and knowledge level of mothers.

\section{Conclusion}

In the present study the investigator intended to assess the Knowledge of mothers regarding Prevention and home care management of chickenpox at Naini, Allahabad.

\subsection{Implications of the Study}

The findings of this study have implications in various areas of nursing namely: nursing practice, nursing education, nursing administration and nursing research.

\section{Nursing Practice}

The focus of health professionals is directed towards primary care-giving. This study helps health professionals to understand the prevention and home care management of chickenpox. The main preventive strategies can be maintained in order to avoid complications of Chickenpox etc... The nurse; during her practice in hospitals or even in the community field can play her magnificent role in eliminating the darkness of public ignorance about Chickenpox. They can also help the mothers in the effective management of Chickenpox among children [32-34]

\section{Nursing education}

Education is a key component in improving the knowledge of an individual. Education in nursing has a vital role to play because the students who are learners today are going to deal with tomorrow's patient. Hence, the right method of 
education with an opportunity to practice and apply what has been taught is essential. Nursing teachers should emphasize on prevention and management of Chickenpox [35-37].

Nurse educators should focus caregivers as a special population at risk. Support can be planned theoretically and information materials, alternative therapies, and training sessions can be formulated to provide inpatient and community care areas. Nurse as an administrator has a crucial role in planning the policies for imparting health information to the patients and diabetic clients. Nursing administration must see that a separate budget should be allocated for in-service education in the nursing department [38-41].

\subsection{Limitations}

1. The study was limited to 60 mothers residing at Naini, Allahabad.

2. The study was limited for mothers who are between the age group of 25-45 years.

3. The study is limited to mother's having children between 1 to 10 years of age in a selected area.

\subsection{Recommendations}

On the basis of the findings of the study the following recommendations have been made:

1. A similar study can be done to assess the risk factors of chickenpox adaptability.

2. A similar study can be replicated on a large number of samples to generalize the findings.

3. A similar study can be conducted by including additional demographic variables.

4. A study can be carried out the efficiency of structured teaching programme.

\section{Acknowledgements}

The authors thank Rev. Fr. K.K. Antony, Director, Nazareth Hospital, Allahabad (India) for granting permission to publish this manuscript.

\section{Conflict of interest}

There is no conflict of interests. This is a case report, and the research has not been sponsored by any organization.

\section{Competing interest: None}

\section{Funding/financial support: None}

\section{References}

[1] Article related to incidence of chickenpox. J. Clinical evidences.2001; 22(11):667-687. Available from URL: http://clinical evidence.bmj.com.

[2] Article related to incidence of chickenpox from professional guide to diseases. Edition-8, 2005. Available from URL: http://www.wrongdiagnosis.com.

[3] Wikipedia the free encyclopedia. Article related to chickenpox. Available from URL: http://www.en.wikepedia.org.

[4] Heather, Brannon.M.D. Varicella viral infection. J. Dermatology 2010. 22:332-343. Available from URL: http://dermatology. About .com.

[5] Jason's. Glanz, David.L. Parental refusal of varicella vaccination. J. Sciencedirect. 2010, 164(1):66-70.

[6] Kristine.M.sevaryn. Chickenpox vaccine.2005, Availablefrom URL: http://www.ncbi.nlm.nih.gov/pubmed.

[7] Article related to country statistics. Available from URL: http://www.wrong diagnosis.com.

[8] A.S. Girija, M. Rafeeque, K.P.Abdurchman. Neurological complications of chickenpox. Available from URL: http://www.ncbi.nlm.nih.gov/pubmed.

[9] De Wals P, Blackburnm M, Guay M. Burden of chickenpox on families. Can j infect dis, 2001; 12(1):27-32. Available from URL: http://www.ncbi.nlm.nih.gov.

[10] Annchen W.A, Daryl's, Wissler. Postpartum mothers knowledge, attitude and trust regarding vaccination. Volume12, Sno-6,766-773. Available from URL: http://www.springlink.com

[11] M.C. Dendrick, M.W.Lau J, Alstons. Potential utilization of varicella vaccine in prevention during pregnancy. Volume 55, Issue 1, 64-67. Available from URL: http://linking hub Elsevier.com.

[12] Poulsen A, Qureshi K, Lisse I. A household study of chickenpox. From journal of infection. 2002, 45(4); 237-42. Available from URL: http://www.ncbi.nlm.nih.gov.

[13] Pinguier D, Gagneur A, Balu L. Prevalance of AZV antibodies. From article of clinical \& vaccine immunology, 2009, 484-487. Available from URL: http://cvi.asm.org. 
[14] Linder N, Ferber A, Kopilov U, Smetana Z. A predictor of positive AVZ antibodies in parturient women. 2001; 16:222-232,. Available from URL: http://content.karger.com.

[15] Mattson S.N, Jones K.L, Grambling L.J, Schonfeld A.M. Neurodevelopmental follow- up children of women infected with varicella during pregnancy. 2003, sep22 (9):819-823. Available from URL: http://www.ncbi.nlm.nih.gov.

[16] Saez-Llorens X, De Sumano, De Moros D, Rubio M.del P. Complications and costs associated with chickenpox.2002; 12(2), 111-116. Available from URL: http://www.ncbi.nlm.nih.gov.

[17] Bohlke K, Galil K, Jackson L.A, Schmid I.S. Is the vaccine virus excreted in breast milk? 2003, 102(5): 970-977. Available from URL: http://www.sciencedirect.com.

[18] Enders G, Miller E, Cradock-Watson J. Consequences of varicella and herpes zoster in pregnancy. 1994; 343(8912):1548-50/. Available from URL: http://www.ncbi.nlm.nih.gov.

[19] Benin A.L, Wilser-Scher D.J, Colson E. Mother's decision making about vaccines for infants. 2006; 117: 1532-1541. Available from URL: http://pediatrics.apublication.org.

[20] Troughton J.A, Crealey G, Crawford V, Coyle P.V. Management of varicella contacts in pregnancy. From journal of clinical virology. 2009, 46(4):345-348. Available from URL: http;//www.ncbi.nlm.nih.gov.

[21] Polit D.F, Hungler B.P. Nursing research; principles and methods. Philadelphia: JB, Lippincott St Company; 2003. http://www.ncbi.nlm.nih.gov/pubmed.

[22] Bilckej, Oqunijimi B, Marais C, DE Smet F.Tthe health and economic burden of chicken pox and Herpes zoster. 2012; 10:1-14. http://www.ncbi.nlm.nih.gov/pubmed.

[23] Najaf zarden M, Marra CA. Cost effectiveness of herpes zooster infection. 2009; 27(12): 991-4. http://www.ncbi.nlm.nih.gov/pubmed.

[24] Mick G. Vaccination of chickenpox. 2010; 9:31-5. http://www.ncbi.nlm.nih.gov/pubmed.

[25] Wumf, Yang, Linway. Varicella zooster infection among Health care Workers. 2011, http://www.ncbi.nlm.nih.gov/pubmed.

[26] Apsarnatha narak A, Kitphate R. Out of varicella zooster infection. 2001; 28(4): 430-4. http://www.ncbi.nlm.nih.gov/pubmed.

[27] Galea SA, Sweet A, Beninger P. The safety profile of Varicella vaccine. 2008; 1:197. http://www.ncbi.nlm.nih.gov/pubmed.

[28] Cameron JC, Allance, Johnston F. Severe complication of chickenpox in hospitalised children. 2007; 92(12): 1062-6. http://www.ncbi.nlm.nih.gov/pubmed.

[29] Zlebold C, Von tries R.Severe complication of Varicella in Previously Healthy children. 2001 ; $108(5) ; 79$. http://www.ncbi.nlm.nih.gov/pubmed.

[30] Joranovic J, Evietkovic . Primary infection varicella zooster infection in risk groups. 1998; 51(3-4):151-4 http://www.ncbi.nlm.nih.gov/pubmed.

[31] Tyring ST, Beater K, Tacker BA. Antiviral therapy for herpes zooster virus. 2008: 9(9); 863-9. http://www.ncbi.nlm.nih.gov/pubmed.

[32] Madkan VK, Arora A. Open label study of Valacyclovir closer for the treatment of complicated HZV in immunocompetent patients. 2007; 11(3):89-98. http://www.ncbi.nlm.nih.gov/pubmed.

[33] Andreia, Snoock R, Emerging drugs for varicella zooster infection. 2011, Sep; 16(3):507-35. http://www.ncbi.nlm.nih.gov/pubmed.

[34] Mollet E, Moitro M. Evaluate of varicella complications. 2004; 11(9):1145-51. http://www.ncbi.nlm.nih.gov/pubmed.

[35] Pheah HX, Chongcy. Complicated varicella zooster infection in paediatric clients. 1998; 39(3):115-20. http://www.ncbi.nlm.nih.gov/pubmed.

[36] Kim JI, Jung GS, Port Hs. Sequencing and characterization of varicella zooster vaccine. 2011; 8(1):547. http://www.ncbi.nlm.nih.gov/pubmed.

[37] Chang LY, Heary LM, Chang Is. Epidemiological characteristics of varicella. 2011, 11(1):352. http://www.ncbi.nlm.nih.gov/pubmed.

[38] Wood SM, Shah SS. Primary Varicella and HIV infected child. 2008, 121(1). http://www.ncbi.nlm.nih.gov/pubmed.

[39] Nancy Burns, Susan K.Grove. Understanding of research. $2^{\text {nd }}$ Edition. New Delhi: Sunderspublishers; 2002.pp.39-40,140.

[40] B.T.Basavanthappa. Fundamentals of nursing. Jaypee Brothers medical publishers (p) Ltd; New Delhi: 1st Edition.1998. pp.86-93.

[41] Marriner-Tomey.Nursing theories and their work. Mosby Publishers; Indiana: $3^{\text {rd }}$ Edition.pp. 359 . 